\title{
STRENGTH CHARACTERIZATION OF FOUNDATION SOILS AT FEDERAL UNIVERSITY LOKOJA BASED ON STANDARD PENETRATION TESTS DATA
}

\author{
J. A. Sadeeq ${ }^{1}$ and A. B. Salahudeen ${ }^{2, *}$ \\ 1 Department of Civil Engineering, Ahmadu Bello University, Zaria, Kaduna State, NigERIA. \\ 2 Samaru College of Agriculture, Div. of Agric. Colleges, Ahmadu Bello Univ., Zaria, Kaduna State, NiGERIA. \\ Email addresses: ${ }^{1}$ jasadeeq@yahoo.com,2 basalahudeen@gmail.com
}

\begin{abstract}
Strength characteristics of foundation soils in the Permanent site of the Federal University Lokoja in Kogi State were evaluated based on standard penetration test (SPT) results using some conventional analytical models proposed by different researchers. The study was carried out in order to take precise engineering decisions on the type of foundations suitable for the proposed structures and to determine the optimal depth of foundation embedment. The SPT $N$-values were first corrected to the standard average energy of $60 \%$ (N60) before they were used to correlate soil properties. Evaluation of the soil properties were done at foundation embedment depths of 0.6, 2.1 and 3.6 m. Results show that bearing capacity generally increased with boring depth. Based on the Meyerhof allowable bearing pressure estimation method, foundation pressures in the range of $150-600 \mathrm{kN} / \mathrm{m}^{2}$ were evaluated for use in the study area at shallow depths (depths in the range of $0.6-3.6 \mathrm{~m}$ ).
\end{abstract}

Keywords: Strength characteristic, Bearing capacity, Foundation, Standard Penetration Test.

\section{INTRODUCTION}

Bearing capacity and settlement are the major considerations in designing shallow foundations on granular soils. The designers try to ensure sufficient safety factor against bearing capacity failure and to limit the settlement within a tolerable value. Several techniques based on stress characteristics, and on upperand lower-bound theorems of limit analysis, have been used to calculate bearing capacity factors for structural footings [1]. One of in situ testing methods is the Standard Penetration Test (SPT) that is used to identify soil type and stratigraphy along with being a relative measure of strength [2]. In this study, the SPT blow count was used as a parameter for in situ characterization of field deposits. SPT primarily gives idea about shear strength of soil which can be expressed in terms of shear strength parameters (c \& $\varphi$ ) [3]. Most laboratory tests must be performed on moulded samples of soils. These tests are laborious and time consuming and sometimes the results are not accurate due to the poor laboratory conditions [4].

Housing demands due to the growing population and migration of people to urban areas in Nigeria, coupled with the fact that the limited areas of land suitable for building constructions are gradually being depleted, construction on less desirable soils such as soft saturated clays and silts is increasing in order to meet the demands of the society [5-7]. These demands require alternative construction methods that provide fast, safe and affordable quality housing. However, some Nigerian soils are problematic and adversely affect foundations of structures there by compromise the stability of the structures founded on them. These soil problems have resulted to excessive settlement, tilting and collapse of many buildings not only in Nigeria but also around the world $[6,8]$.

The Federal University Lokoja, Kogi state, was one of the eight (8) federal universities approved by the Federal Government of Nigeria on $16^{\text {th }}$ February, 2011. The University started course program in 2012/2013 session at the temporary site, Adankolo Campus, located within Lokoja. The permanent site (the study area) is located at Felele, Lokoja, Kogi state which covers a land area of about 800ha. This site is expected to accommodate the University structures and facilities which are intended to grow into full maturity over a period of 10 to 15 years. As a pre-requisite for the development of the site, a physical development master plan for the site is required which include the topographical and boundary survey of the site, geotechnical and groundwater profiling, environmental impact assessment and development of the master plan of the site. This study is aimed at

\footnotetext{
* Corresponding author, tel: + 234-909-068-9549
} 
investigating the subsoil conditions in the study area (Permanent site of Federal University, Lokoja located in Kogi State) based on geotechnical site exploration methodology in order to take precise engineering decisions on the type of foundations suitable for the proposed structures, to determine the best depth of foundation embedment and best locations for different utilities. Kogi State map showing the location of the study area is shown in Figure 1.

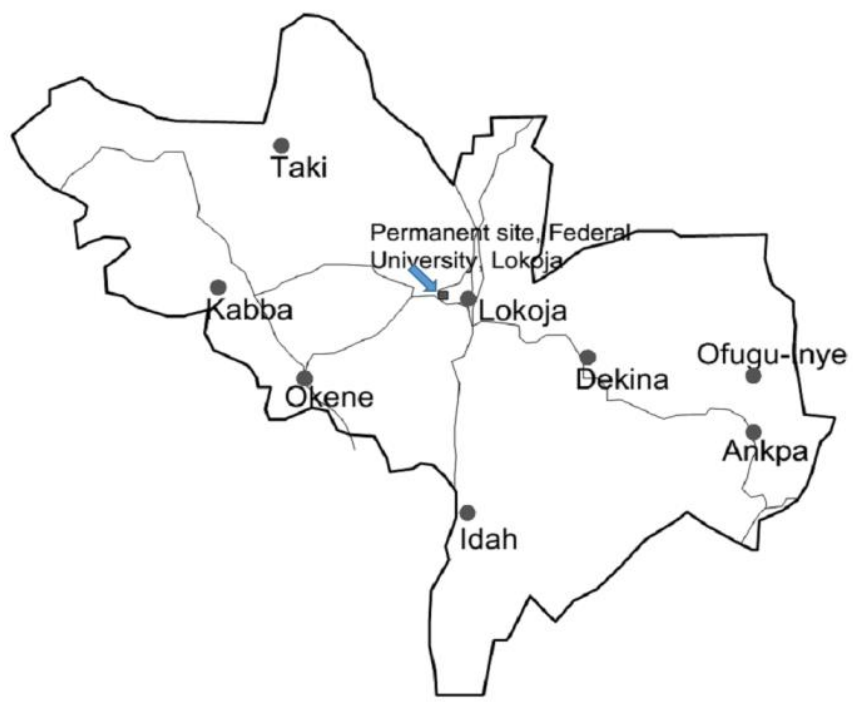

Figure 1: Kogi State map showing the location of the study area

\section{RESEARCH METHODOLOGY}

Standard penetration test (SPT) data (using Donut hammer type) was collected from 10 test holes (30 data set, note that several trial pits were used to cover the whole study area) distributed over the study area.
Strength characteristics estimations were made at depths of 0.6, 2.1 and $3.6 \mathrm{~m}$ using the analytical models presented in Table 1. Allowable bearing pressure estimation was performed using the method of Meyerhof [9] due to its general acceptance.

Standard penetration test: The standard penetration test (SPT) (see Figure 2) consists of driving a standard split barrel sampler a distance of $460 \mathrm{~mm}$ into the soil at the bottom of the boring, counting the number of blows to drive the sampler the last two $150 \mathrm{~mm}$ distances (to obtain the $\mathrm{N}$ number) using a $63.5 \mathrm{~kg}$ driving hammer falling free from a height of $760 \mathrm{~mm}$ [10]. The boring log shows refusal if 50 blows are required for any $150 \mathrm{~mm}$ penetration, 100 blows are obtained for a $300 \mathrm{~mm}$ penetration or 10 successive drops of the hammer produce no advance in penetration. The SPT was conducted in accordance with ASTM D-1586-99 [11]. The standard split tube sampler has an inside diameter of $34.93 \mathrm{~mm}$ and an outside diameter of $50.8 \mathrm{~mm}$. The numbers of blows required for a spoon penetration of three $150 \mathrm{~mm}$ intervals are recorded. The number of blows required for the last two intervals are added to give the standard penetration number, $\mathrm{N}$, at that depth. This number is generally referred to as the $\mathrm{N}$-value which was a correction to an average energy ratio of $60 \%\left(\mathrm{~N}_{60}\right)$. SPT was conducted at depth intervals of 1.5 $\mathrm{m}$. The correction factors used in the study are those proposed by [12 - 13] to standardize the field penetration number as a function of the input driving energy and its dissipation around the sampler into the surrounding soil.

Table 1: Analytical models for soil parameters analysis [23]

\begin{tabular}{|l|c|}
\hline Property & Model \\
\hline Corrected N-value $\left(\mathrm{N}_{60}\right)$ & $N_{60}=\frac{N \eta_{H} \eta_{B} \eta_{R}}{60}$ \\
\hline Overconsolidation Ratio & OCR $=0.193\left(\frac{N_{60}}{\sigma_{0}^{1}{ }_{0}^{0.689}}\right.$ \\
\hline Rigidity index & $I_{R} \approx \frac{\exp \left(\frac{137-P I}{23}\right)}{\left[1+\operatorname{In}\left(1+\frac{O C R-1}{26}\right)^{3.2}\right]^{0.8}}$ \\
\hline Relative density & $D_{r}(\%)=12.2+0.75\left[222 N_{60}+2311-7110 C R-779\left(\frac{\sigma_{O}^{x}}{P_{a}}-50 C_{u}^{2}\right)\right]^{0.5}$ \\
\hline Angle of internal friction & $\emptyset^{\prime}(\mathrm{deg})=27.1+0.3\left[\left(N_{1}\right)_{60}\right]-0.00054\left[\left(N_{1}\right)_{60}\right]^{2}$ \\
\hline Undrained shear strength & $C_{u}=0.29 P_{a} N_{60}^{0.72}$ \\
\hline Unconfined compressive strength & $q_{u}=0.58 P_{a} N_{60}^{0.72}$ \\
\hline Allowable bearing capacity & $q_{a}=0.32\left(N_{1}\right)_{60} R_{D}\left(\frac{B+0.3}{B}\right)^{2} S_{a}$ \\
\hline
\end{tabular}




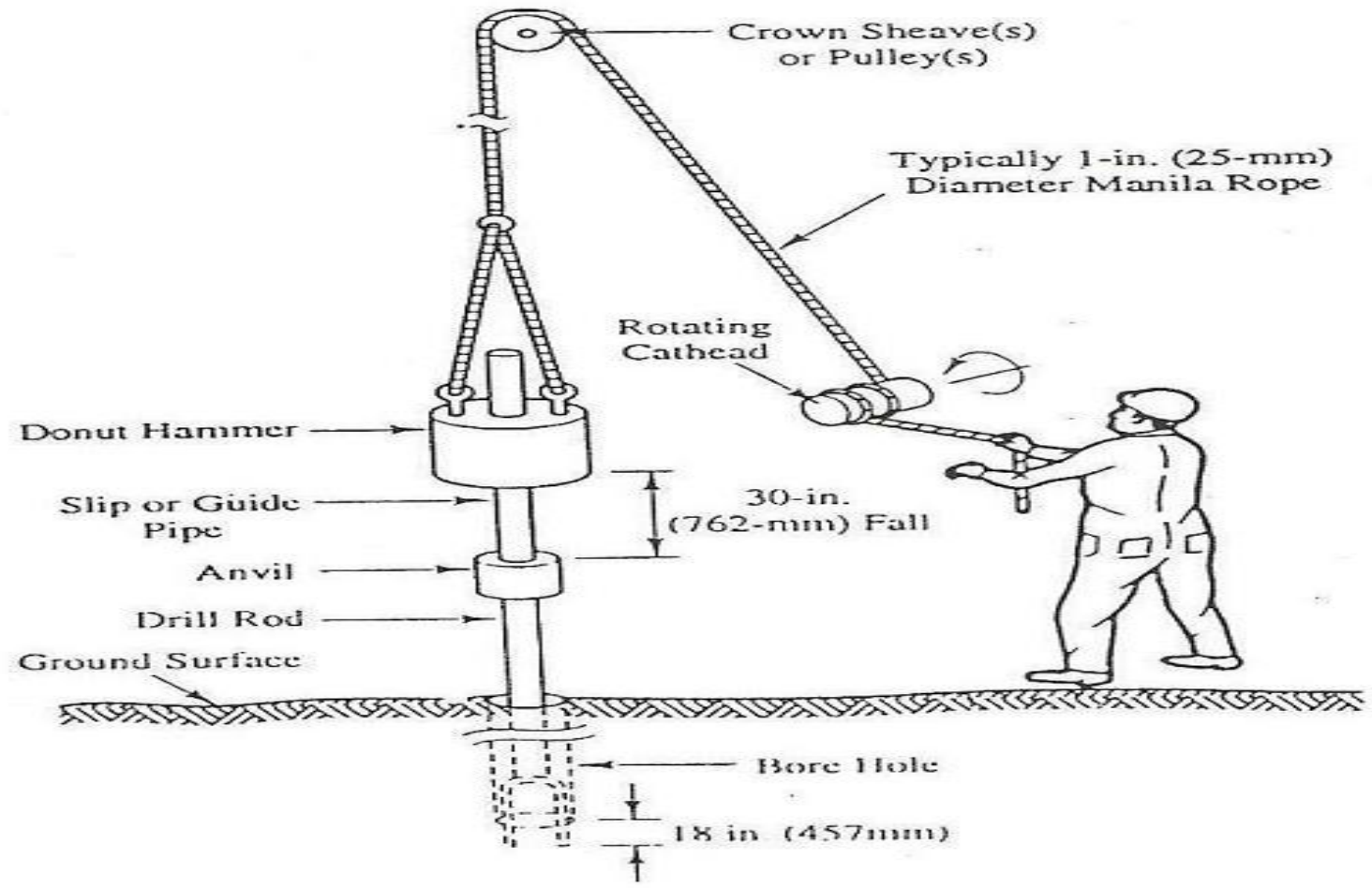

Figure 2: The set-up and SPT equipment

\section{RESULTS AND DISCUSSION}

\subsection{Corrected $\mathrm{N}$-values $\left(\mathrm{N}_{60}\right)$}

The variation of $\mathrm{N}_{60}$ with depth of test is shown in Figure 3. $\mathrm{N}_{60}$ increased with depth having the highest value of 89.25 .

\subsection{Overconsolidation Ratio and Rigidity Index}

The degree of preconsolidation is usually expressed in terms of the overconsolidation ratio (OCR), it is the ratio of the maximum overburden stress a soil has ever experienced to the present overburden stress. It is important to point out that any correlation between the $\mathrm{N}_{60}$ and the OCR is only approximate [13]. Mustapha and Alhassan [14] reported OCR value of 16.9 at $1 \mathrm{~m}$ depth from some selected Northern Nigerian soil deposits using laboratory tests. The variations of OCR and rigidity index

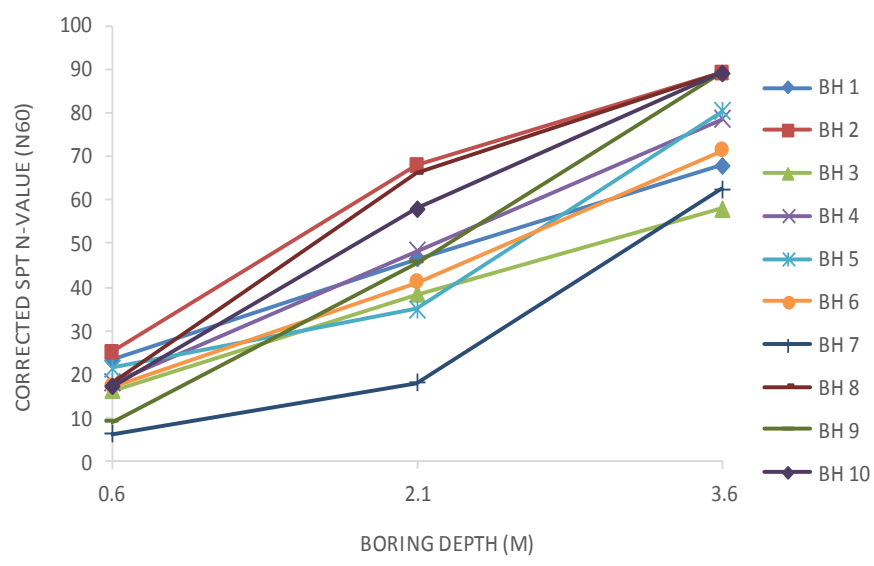

Fig. 3: Variation of corrected SPT N-values with boring depth with boring depth are shown in Figures4and 5 respectively. The OCR values decreased with boring depth on the average while those of rigidity index increased with boring depth.

However, the OCR index does not always unambiguously reflect changes in strength parameters generated as a consequence of the overconsolidation process. Processes affecting soil deposit overconsolidation may overlap, especially in surface parts of subsoil. These processes may include changes in ground water level and run-off pressure they caused, cementation or reconstruction of structure as a result of deposit creep. OCR is used to identify and indicate in subsoil successive phases of deposit accumulation, separated by stratigraphy gaps [15].

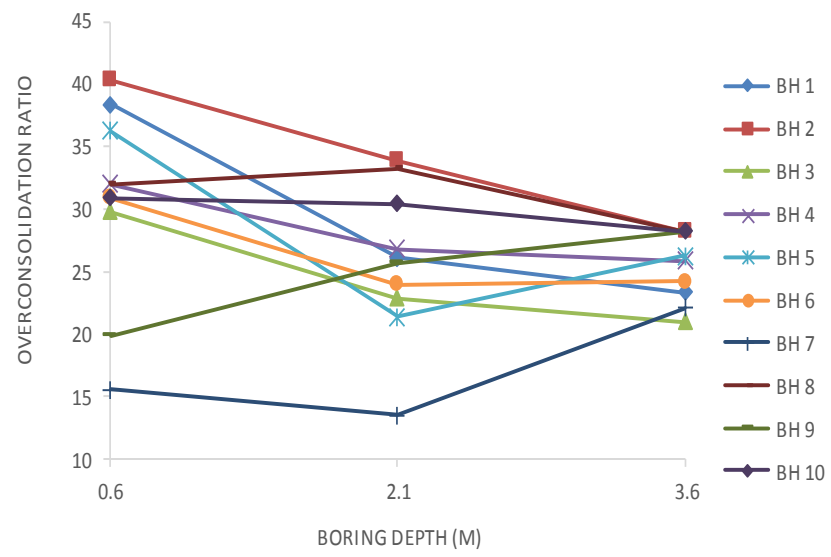

Figure 4: Variation of Overconsolidation ratio with Boring Depth 


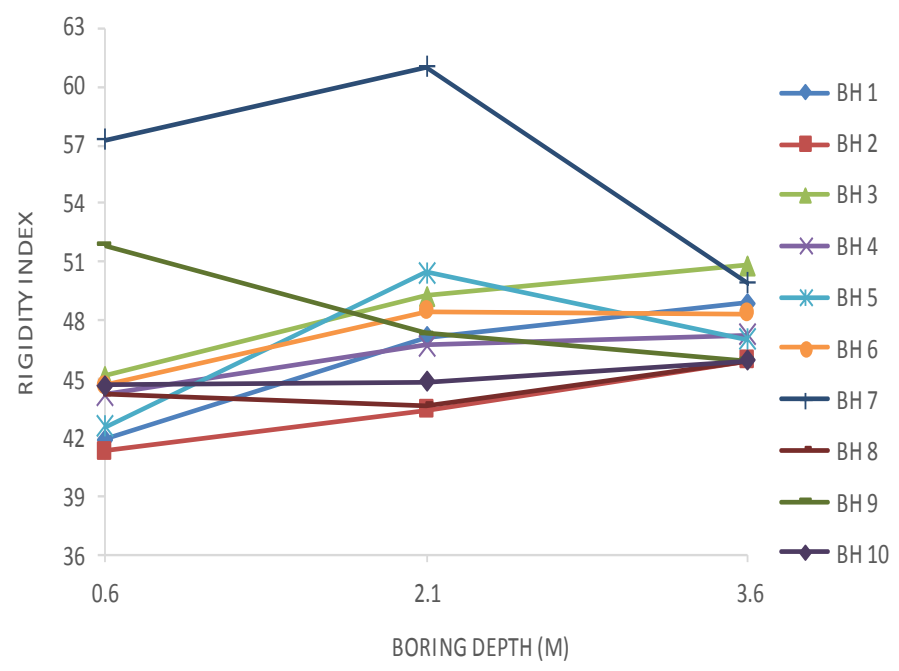

Figure 5: Variation of rigidity index with boring depth

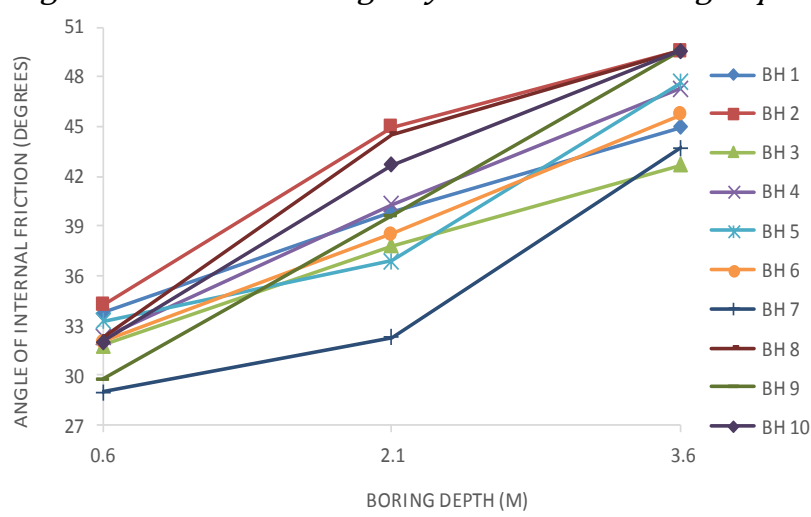

Figure7: Variation of angle of internal friction with boring depth

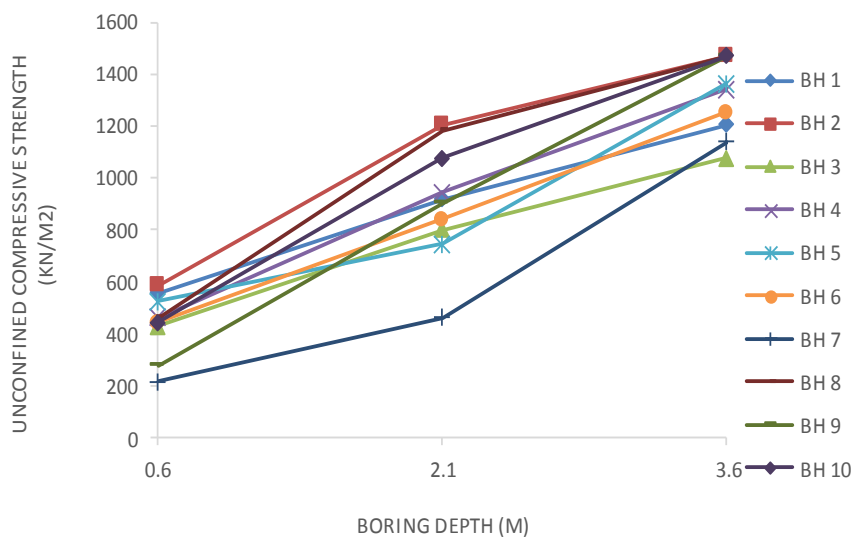

Figure 9: Variation of unconfined compressive strength with boring depth

For the evaluation of the relative compressibility of a soil mass under loaded conditions, Vesic [16] introduced a term called rigidity index which was developed on the basis of the theory of expansion of cavities in an infinite solid with the assumed ideal elastic properties behaviour of soil [13]. Rigidity index, which is the ratio of the shear modulus to the undrained shear strength of the soil, varies with the stress level and the character of loading. Krage et al. [17] indicated that the higher the overconsolidation ratio the lower the rigidity index. The

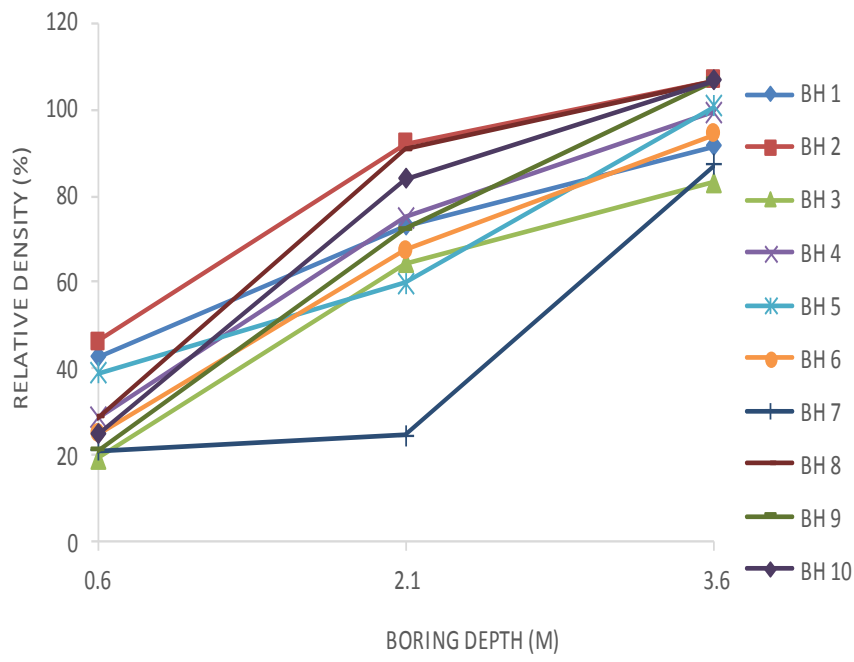

Figure 6: Variation of relative density with boring depth

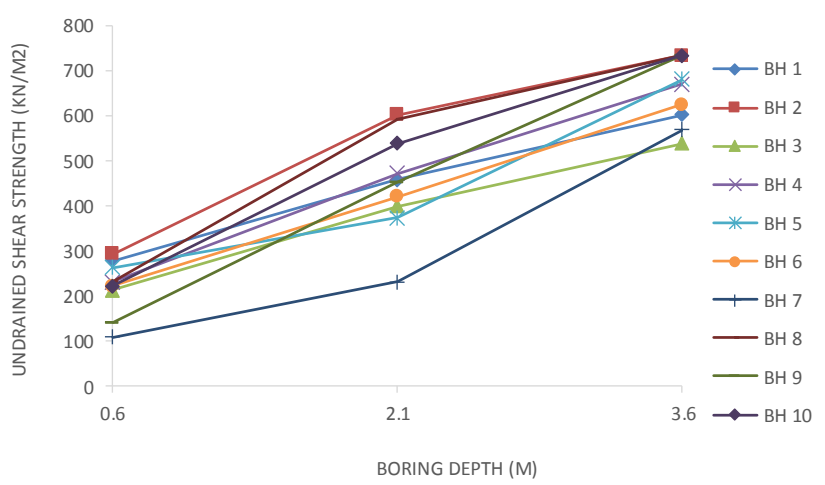

Figure 8: Variation of undrained shear strength with boring depth

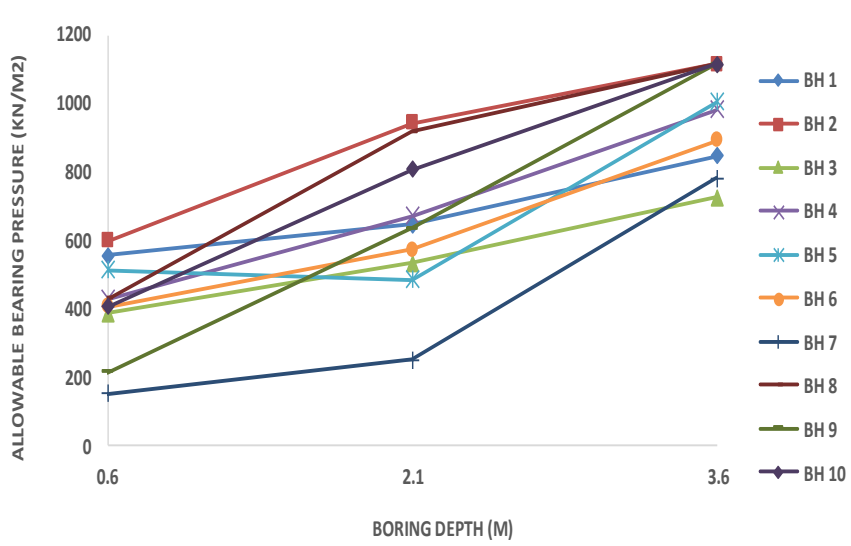

Figure 10: Variation of allowable bearing pressure with boring depth

variation of rigidity index with depth shown in Figure 3 shows the reverse of the overconsolidation ratio.

\subsection{Relative Density}

Relative density (or density index) is the measure of compaction of non-cohesive soils naturally compacted as a result of geological processes. The values are approximate, primarily because the effective overburden pressure and the stress history of the soil significantly influence the values in sand. Due to its formulation, relative density prediction is prone to large errors. The 
relationships between relative density and field tests are not unique and are strongly influenced by other parameters such as fines content, grain size and grain shape, grading and grading curve shape, effective vertical or horizontal stresses, mineralogy, compressibility and crushability, cementation, overconsolidation and age [18].

The variation of relative density with depth is shown in Figure 6 . The highest density of $106.81 \%$ was obtained at 3.6 m depth of BH 2, 8, 9 and 10. Soil with higher density is always associated with higher mobilised angle of shearing resistance [19]. Relative density has a significant effect on penetration resistance and can be correlated. Bolton and Gui [19] also revealed that it is not easy to achieve a consistent density for a specimen with relative density of less than $60 \%$.

\subsection{Strength Characteristics}

The variations of the angle of internal friction, undrained shear strength and unconfined compressive strength with depth are shown in Figures7 - 9. The shear strength of a soil mass is the internal resistance per unit area that the soil mass can offer to resist failure along any plane inside it. When this resistance is exceeded failure occurs. Shear strength within a soil matrix is due to cohesive and frictional forces between adjacent particles [20]. Therefore, angle of internal friction, is one of the important parameters of soil strength. Angle of internal friction could be described as a measure of the ability of a unit of rock or soil to withstand a shear stress. The unconfined compression test is used to measure the shearing resistance and bearing capacity of soils. Value of undrained shear strength without confining pressure is equal to unconfined compressive strength. This value is theoretically twice as big as cohesion [21]. The three parameters are found in this study to be highest at $3.6 \mathrm{~m}$ depth.

\subsection{Allowable Bearing Capacity}

Based on field test results, the bearing capacities of shallow foundations are determined in terms of the allowable bearing pressures while those of deep foundations (piles) are given in terms of the ultimate bearing capacity. This is because settlement (service limit) controls the allowable bearing capacity in design of shallow foundations while the ultimate limit (shear failure) usually controls the allowable bearing capacity in deep foundations design [6, 7]. For the allowable bearing pressures of shallow foundations, footing plan dimensions of $2 \mathrm{~m}$ by $2 \mathrm{~m}$ by $0.4 \mathrm{~m}$ for length, breadth and depth, respectively were assumed with safety factor of 3. Variations of allowable bearing capacity with boring depth are shown in Figure 10. Based on the Meyerhof [9] allowable bearing pressure estimation method used in this study, foundation pressures in the range of 150 $600 \mathrm{kN} / \mathrm{m}^{2}$ were evaluated for use in the study area at shallow depths (depths in the range of $0.6-3.6 \mathrm{~m}$ ). Atat et al. [22] suggested an average allowable bearing pressure of $154.78 \mathrm{kN} / \mathrm{m}^{2}$ for shallow foundations in Akwa-Ibom State.

\section{CONCLUSION}

Standard penetration test (SPT) results corrected to the standard average energy of $60 \%\left(\mathrm{~N}_{60}\right)$ correlated to soil properties were used in this study for the evaluation of foundation soil strength characteristics in the Permanent site of the Federal University Lokoja in Kogi State. Based on the results of this study, the following were concluded:

1. The results of overconsolidation ratio, rigidity index, relative density, angle of internal resistance, undrained shear strength and unconfined compressive strength show that the strength characteristics of soils in the study area is high on the average.

2. The strength parameters evaluated which indicated that the foundation soils bearing capacity values will be high in the study area were confirmed by the allowable bearing capacity results.

3. Based on the Meyerhof [9] allowable bearing pressure estimation method used in this study, foundation pressures in the range of $150-600$ $\mathrm{kN} / \mathrm{m}^{2}$ were evaluated for use in the study area at shallow depths (depths in the range of $0.6-3.6 \mathrm{~m}$ ).

\section{REFERENCES}

[1] Osman, A. S. and Bolton, M. D. "Simple plasticitybased prediction of the undrained settlement of shallow circular foundations on clay". Geotechnique 55, No. 6, 435-447,2005.

[2 Al-Jabban, M. J. W. “Estimation of Standard Penetration Test (SPT) of Hilla City-Iraq by Using GPS Coordination". Jordan Journal of Civil Engineering (JJCE), Volume 7, No. 2, 133-145, 2013.

[3] Abdou, M. and Mahmoud, N. A. "Reliability of using standard penetration test (SPT) in predicting properties of silty clay with sand soil". International Journal of Civil and Structural Engineering (IJCSE), Vol. 3, No 3, 545-556. 2013.

[4] Venkatasubramanian. C. and Dhinakaran.G."ANN model for predicting CBR from index properties of soils". International Journal of Civil and Structural Engineering (IJCSE), Vol. 2 No. 2, 614-620, 2011.

[5] Salahudeen, A. B., Ijimdiya, T. S., Eberemu, A. O. and Osinubi, K. J. Prediction of bearing capacity and settlement of foundations using standard penetration data in the South-South geo-political zone of Nigeria, Book of Proceedings, International 
conference on Construction Summit, Nigerian Building and Road Research Institute (NBRRI), 2016a.

[6] Salahudeen, A. B., Eberemu, A. O., Ijimdiya, T. S. and Osinubi, K. J. Prediction of bearing capacity and settlement of foundations in the south-east of Nigeria, Book of Proceedings, Material Science and Technology Society of Nigeria (MSN) Kaduna State Chapter conference, July16, NARICT, Zaria, 2016b.

[7] Salahudeen A. B. and Sadeeq, J. A., Evaluation of bearing capacity and settlement of foundations, Leonardo Electronic Journal of Practices and Technologies (LEJPT), Issue 29, Pp. 93-114, 2016.

[8] Katzenbach, R., Bachmann, G. and Ramm, H "Combined Pile Raft Foundation (CPRF): An Appropriate Solution for Foundation of High-Rise Building." Sloak Journal of Civil Engineering (SJCE), p. 19-29, 2005.

[9] Meyerhof, G. G. "Penetration Testing Outside Europe: General Report", Proceedings of the European Symposium on Penetration Testing, Vol. 2.1, pp 40-48. Available from National Swedish Institute for Building Research, P. O. Box 785, S801-29-GAVLEÄ, Sweden, 1974..

[10] Bowles, J. E. Foundation analysis and design. 5th Edition, McGraw-Hill Book Co., New York, USA. Cohen, J. (1988). "Statistical power analysis for the behavioural sciences." 2nd Edition. New Jersey: Lawrence Erlbaum, 1996.

[11] American Society for Testing and Materials "Standard Test Method for Penetration Test and Split Barrel Sampling of Soils (D1586)". ASTM International, West Conshohocken, 2001.

[12] Bezgin, 0. "An insight into the theoretical background of: Soil structure interaction analysis of deep foundations". A technical report, Istanbul, 2010.

[13] Das, B. M. "Principles of foundation engineering, SI". 7th edition, 133, 2011.

[14] Mustapha, A. and Alhassan M. "Overconsolidation Ratio of Some Selected Soil Deposits in Nigeria."
Scholars Journal of Engineering and Technology (SJET), Vol. 1 No. 4, pp 183-186, 2013.

[15] Wierzbicki, J. "Analysis of changes in overconsolidation ratio in selected profiles of nonlithified deposits. The ACE Journal, Silesian University of Technology No. 3, pp 77-84, 2009.

[16] Vesic, A. S. "Expansion of cavities in infinite soil mass." J. Soil Mech. And Found. Div., ASCE, Vol. 98 No.3, pp. 265-290, 1972.

[17] Krage, C. P., Broussard, N. S. and DeJong, J. T. "Estimating rigidity index (IR) based on CPT measurements." Third International Symposium on Cone Penetration Testing, Las Vegas, Nevada, USA pp. 727-735. 2014.

[18] Hamidi, B., Nikraz, H. and Varaksin, S. "Invalidity of relative density for quality control of cohesionless soils." Australian Geomechanics Society - GFWA, 2013.

[19] Bolton, M. D. and Gui, M. W. "The study ofrelative density and boundary effects for cone penetration tests in centrifuge CUED/D-SOILS/TR256, Cambridge University UK, 1993.

[20] Adunoye, G. O. "Fines content and angle of internal friction of a lateritic soil: An Experimental study." American Journal of Engineering Research (AJER), Vol.03, No. 03, pp 16-21, 2014.

[21] Widodo, S. and Ibrahim, A. "Estimation of primary compression index using physical properties of pontianak soft clay." International Journal of Engineering Research and Applications (IJERA) Vol. 2, No. 5, pp. 2232-2236, 2012.

[22] Atat, J. G., Akpabio, I. O. and George, N. J. "Allowable bearing capacity for shallow foundation in Eket Local Government Area, Akwalbom State, Southern Nigeria." International Journal of Geosciences, Vol. 4, pp 1491-1500, 2013.

[23] Salahudeen, A. B. "Prediction of foundation settlement based on standard penetration test results using empirical and numerical techniques." Unpublished PhD thesis, Department of Civil Engineering, Ahmadu Bello University, Zaria, Nigeria. Pp 70 - 77, 2017. 